\title{
Hydrothermal Conversion of Spent Sugar Beets into High-Value Platform Molecules
}

\author{
Jens Pfersich ${ }^{1, *(\mathbb{D})}$, Pablo J. Arauzo ${ }^{1}$, Michela Lucian ${ }^{2}\left(\mathbb{D}\right.$, Pierpaolo Modugno ${ }^{3}$, \\ Maria-Magdalena Titirici ${ }^{4}$, Luca Fiori ${ }^{2}$ (D) and Andrea Kruse ${ }^{1}$ (D) \\ 1 Conversion Technologies of Biobased Resources, University of Hohenheim, Garbenstrasse 9, \\ 70599 Stuttgart, Germany; Pabloj.Arauzo@uni-hohenheim.de (P.J.A.); \\ Andrea_Kruse@uni-hohenheim.de (A.K.) \\ 2 Department of Civil, Environmental and Mechanical Engineering, University of Trento, Via Mesiano 77, \\ 38123 Trento, Italy; Michela.Lucian@unitn.it (M.L.); Luca.Fiori@unitn.it (L.F.) \\ 3 School of Engineering and Materials Science, Queen Mary University of London, Mile End Road, \\ London E1 4NS, UK; P.Modugno@qmul.ac.uk \\ 4 Department of Chemical Engineering, Imperial College London, South Kensington, London SW7 2AZ, UK; \\ M.Titirici@imperial.ac.uk \\ * Correspondence: Jens.Pfersich@uni-hohenheim.de; Tel.: +49-711-459-24709
}

Academic Editor: Silvia Roman Suero

Received: 27 July 2020; Accepted: 26 August 2020; Published: 27 August 2020

\begin{abstract}
The growing importance of bio-based products, combined with the desire to decrease the production of wastes, boosts the necessity to use wastes as raw materials for bio-based products.A waste material with a large potential is spent sugar beets, which are mainly used as animal feeds or fertilizers. After hydrothermal treatment, the produced chars exhibited an $\mathrm{H} / \mathrm{C}$ ratio of 1.2 and a higher heating value of $22.7 \mathrm{MJ} / \mathrm{kg}$, which were similar to that of subbituminous coal and higher than that of lignite. Moreover, the treatment of $25 \mathrm{~g} / \mathrm{L}$ of glucose and $22 \mathrm{~g} / \mathrm{L}$ of fructose by heating up to $160{ }^{\circ} \mathrm{C}$ led to a possible application of spent sugar beets for the production of 5-hydroxymethylfurfural. In the present study, the maximum concentration of 5-hydroxymethylfurfural was $3.4 \mathrm{~g} / \mathrm{L}$ after heating up to $200^{\circ} \mathrm{C}$.
\end{abstract}

Keywords: agro-residues; sugar beets; biomass; hydrothermal carbonization; hydrolysis; sugars; HMF; hydrochar; biorefinery

\section{Introduction}

The depletion of current petrochemical reserves to produce energy and fine chemicals, as well as the growth of $\mathrm{CO}_{2}$ emissions, which is one of the factors of climate change [1], motivate to find sources of renewable energies. Biomasses like wood, forestry residues, agricultural wastes and urban wastes are the sole known renewable carbon sources with sufficient carbon content [2] and an environment-friendly neutral $\mathrm{CO}_{2}$ balance.

Thermochemical conversion of biomass is considered as one of the pathways for the production of renewable energy and valuable chemicals or materials. The study of different thermochemical processes such as pyrolysis, gasification, combustion and hydrothermal carbonization (HTC) are well-illustrated in previous studies with model compounds (i.e., microcrystalline cellulose and glucose) for the production of different products [3-5]. On the other hand, the wish to use biomass in the frame of biorefinery still necessitates research to improve the processes and implement different kinds of biomasses. Biorefinery concepts include using complex biomass as feedstock, which contains different amounts and compositions of biopolymers such as hemicellulose, cellulose and lignin. Thus, a comparison of biomasses with model compounds is necessary. 
One of the thermochemical processes which rose notably during the last years due to its simple integration into biorefinery concepts is the process of hydrothermal conversion. This conversion process is considered to be the most suitable for the conversion of wet biomass to gain valuable solid and liquid products which are rich in valuable compounds like furans, organic acids (acetic and levulinic acids) and sugars (glucose and fructose). The selectivity during the conversion of the initial biomass to obtain these compounds in the liquid phase is mainly affected by the process $\mathrm{pH}$, temperature and reaction time [6-9]. Moreover, in the present study, the focus was hydrothermal treatment (HT) of the biomass to obtain a solid product as well as intermediates of the hydrolysis step. Thus, it is necessary to understand how to increase the selectivity of the conversion of intermediate products, which results in high-value chemical compounds, by comprehending the reaction routes originating from the biomass via HT (Figure 1). One of the high-value molecules, which can be obtained during hydrothermal treatment, is 5-hydroxymethylfurfural (HMF). HMF consists of a heterocyclic furan ring with a hydroxyl group as well as an aldehyde group [10,11]. This structure is crucial to mainly undergo reduction (e.g., 2,5-bis(hydroxymethyl)furan), oxidation (e.g., 2,5-furandicarboxylic acid) and esterification reactions [12-14].

Several types of feedstock can be used as raw materials for HMF production: monosaccharides (fructose or glucose), disaccharides (maltose, sucrose or cellobiose) and polysaccharides (starch, inulin or cellulose) [15]. Although fructose is the preferred starting material to obtain optimal HMF yield, it should be clear that biomasses rich in cellulose, the major component in plant biomass, are more suitable for the large-scale production of HMF [16-18].

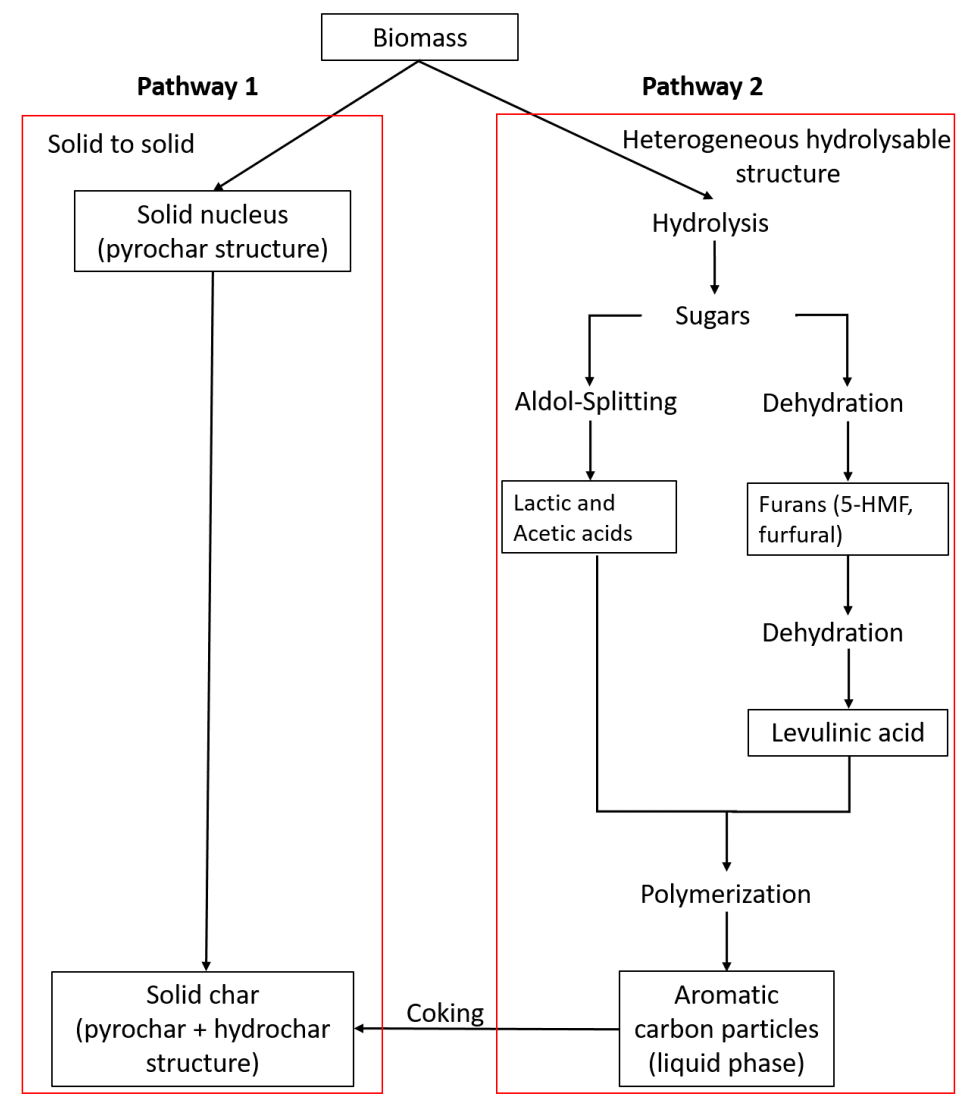

Figure 1. Possible char formation pathways of biomasses (e.g., spent sugar beets (SPB)) during hydrothermal treatment (HT); modified from Kruse et al. and Karaldiyrim [19,20].

The integration of HMF production in biorefinery concepts requires a suitable starting biomass, which initially contains a high amount of glucose to be converted by hydrothermal treatment. One of the biomasses, which fits this purpose, is sugar beets originally containing 15-20 wt.\% sugar [21]. 
The sugar is extracted during industrial processes, while the rest of the plant serves as a mediocre fertilizer or animal feed [21]. In 2018/2019, Südzucker, a leading sugar production company of Germany, produced 4.6 million tons of sugar from 29.4 million tons of sugar beets [22]. Totally, 25\% of the sugar produced worldwide originates from sugar beets [21]. Thus, a high amount of potential feedstock for biorefineries is available, which would be another advantage adding to the short ways between farms and sugar production facilities [23]. After sugar extraction, exhausted sugar beets are called spent sugar beets (SPB).

Therefore, the aim of this study was to evaluate the selectivity and conversion of SPB as an initial feedstock to sugars as a product of HT. Furthermore, intermediate products of the hydrothermal conversion like HMF are discussed. These results are compared with previous studies, which used model compounds to predict the formation of these intermediates.

\section{Results and Discussion}

\subsection{Feedstock Characterization}

Table 1 shows the fiber composition of SPB used for HT tests in this study. It was found that the SPB consists of less cellulose and hemicellulose than raw sugar beets [24]. This difference in composition may be due to the breaking of the original fibers of SPB after sugar production because of thermal treatments (e.g., slicing, cooking and mashing) [25]. In the case of polysaccharides (cellulose and hemicellulose), a higher reduction of the hemicellulose content is obtained compared to cellulose. This is due to the branched chains of hemicellulose and the different monomers and saccharides, which are the building blocks of hemicellulose. While the chains of cellulose can arrange themselves in secondary structures like lamellae and fibers consisting of crystalline areas, thus containing a higher stability against reagent penetration due to its regular structure, hemicellulose is not able to form highly arranged structures [26-28]. Side chains and different monomers cause different distances between the hemicellulose chains, which is the reason for weaker and fewer interactions between the chains [26-28]. Therefore, the chains of hemicellulose appear as easier targets for water, thus being hydrolyzed faster $[26,28]$. Nonetheless, this amorphous structure enables hemicellulose chains to form many interactions with cellulose and lignin, leading to a high stability of the plant material. Furthermore, cellulose also shows a different hydrolysis behavior, which is a result of the amorphous and crystalline structures of cellulose [29]. Differences between the raw sugar beets and the spent sugar beets may be caused by a partial hydrolysis of the amorphous part of cellulose during sugar extraction, while the crystalline structure remains mostly unaffected in the SPB. This agrees with previous studies, which showed that the amorphous structure of the cellulose tends to be hydrolyzed faster than the crystalline structure $[5,30,31]$.

Table 1. Fibers analysis of spent sugar beets (SPB).

\begin{tabular}{cc}
\hline Compound & Content $[\mathbf{w t .} \%$ ] \\
\hline cellulose & 17.3 \\
hemicellulose & 20.0 \\
lignin & 0.6 \\
others & 62.1 \\
\hline
\end{tabular}

\subsection{Solid Characterization}

Table 2 shows the operating conditions of the HT and the physicochemical properties of the obtained solid. The selection of reaction temperatures of $160{ }^{\circ} \mathrm{C}$ and $200{ }^{\circ} \mathrm{C}$ was based on the research of Titirici et al. [32] and Kruse et al. [33]. Cellulose is completely composed of D-glucose units, while hemicellulose also comprises other sugars. At $160{ }^{\circ} \mathrm{C}$, glucose starts to get converted to hydrochar, which is in agreement with other studies that mention that the conversion of hemicellulose during hydrothermal carbonization starts between $160^{\circ} \mathrm{C}$ and $180^{\circ} \mathrm{C}[32,34,35]$. In addition, several 
studies [32,36,37] showed that, at $200^{\circ} \mathrm{C}$, the cellulose structure starts to get degraded and consequently converted into hydrochar. Moreover, the conversion of biomass into char by hydrothermal treatment can proceed via two different pathways. First, direct solid-to-solid conversion, usually associated with lignin, which is referred to as pyrochar. Second, the degradation of hydrolyzed molecules, derived from the volatile matter (VM), to intermediates like furans with a subsequent polymerization to produce coke particles (often referred to as secondary char) [38-40]. Due to the considerably low lignin content in SPB (shown in Table 1), the impact of this first pathway was supposed to be not significant in this study. Hence, the second pathway was considered as the preferred pathway to convert the SBP to hydrochar. As the main field of interest in this study was the conversion of the initial biomass to intermediates, the reaction time started when the reactor reached the reaction temperature. Increasing the operating temperature from $160^{\circ} \mathrm{C}$ to $200{ }^{\circ} \mathrm{C}$ led to an almost time-independent reduction of VM (Table 2).

Table 2. Proximate and ultimate analysis of original biomass and hydrochars.

\begin{tabular}{|c|c|c|c|c|c|c|c|c|}
\hline \multirow[t]{2}{*}{ Sample } & \multicolumn{3}{|c|}{$\begin{array}{l}\text { Proximate Analysis } \\
\text { [wt. } \% \mathrm{db}]\end{array}$} & \multirow[b]{2}{*}{$\mathrm{N}$} & \multicolumn{4}{|c|}{$\begin{array}{c}\text { Ultimate Analysis Dry } \\
{[w \mathrm{t} . \% \mathrm{db}]}\end{array}$} \\
\hline & Volatile Matter & Ash & Fixed Carbon & & $\mathrm{C}$ & $\mathrm{H}$ & $S$ & $\mathrm{O}$ \\
\hline raw & 77.6 & 5.7 & 16.6 & 1.7 & 42.4 & 6.2 & 0.2 & 43.7 \\
\hline S_160 & 73.5 & 5.6 & 20.9 & 2.0 & 45.3 & 5.8 & 0.2 & 41.1 \\
\hline S_160_0.5 & 72.1 & 5.8 & 22.1 & 2.2 & 47.8 & 6.1 & 0.2 & 37.9 \\
\hline S_160_1 & 69.6 & 5.8 & 24.2 & 2.4 & 52.3 & 5.8 & 0.2 & 33.5 \\
\hline S_200_0 & 65.8 & 6.1 & 28.1 & 2.3 & 54.2 & 5.5 & 0.2 & 31.7 \\
\hline S_200_0.5 & 64.9 & 5.6 & 29.5 & 2.3 & 55.0 & 5.5 & 0.2 & 31.5 \\
\hline S_200_1 & 64.5 & 5.6 & 30.0 & 2.1 & 55.8 & 5.4 & 0.2 & 30.8 \\
\hline
\end{tabular}

Table 2 shows that increasing the reaction time from $0 \mathrm{~h}$ to $1 \mathrm{~h}$ only led to a slight decrease of the VM and increase of fixed carbon (FC). While the decrease in the VM and the increase in FC at $160{ }^{\circ} \mathrm{C}$ were around $4 \mathrm{wt} . \%$ by increasing the reaction time to $1 \mathrm{~h}$, the decrement at $200^{\circ} \mathrm{C}$ was around $2 \mathrm{wt} . \%$ for the same increase in reaction time. Moreover, at $160^{\circ} \mathrm{C}$, the yield of hydrochar decreased with the reaction time, which agreed with previous studies [38,39]. However, at $200{ }^{\circ} \mathrm{C}$, the increasing reaction time leads to a contrary effect as previously observed. Thus, it can be assumed that some of the intermediates, which remained in the process water in the experiments for $0 \mathrm{~h}$ and $0.5 \mathrm{~h}$, reacted via a polycondensation mechanism and precipitated to increase the yield of hydrochar.

To confirm this, dissolved organic carbon (DOC) of the liquid samples (Supplementary Information, Table S1) was determined. It was observed that an increase of reaction time led to a reduction of DOC for both temperatures. At $200{ }^{\circ} \mathrm{C}$, this decrease of the intermediates and increase of the yield of hydrochar implied that the conversion of initial VM to intermediates was completed (Table 2). Additionally, at $160^{\circ} \mathrm{C}$, this reduction also implied the formation of coke, often called secondary char. However, the kinetic rate of degradation of the VM was higher than the kinetic rate of formation of coke from intermediates (5-hydroxymethylfurfural and furfural) [39-42].

In this study, a scanning electron microscopy (SEM) analysis was performed to confirm the hypothesis that, mostly the second pathway (formation of hydrochars) takes place [43]. While the raw SPB exhibited a smooth surface and mainly consisted of large pieces, temperature and reaction time showed their impact on the surface of the chars (Figure 2). This uniform surface was changed in two different ways, which included cracking of the huge pieces due to thermal stress and reactions as well as becoming rough because of charring. While cracking of the fibers of the original biomass led to new reaction sites, the charring occurred all over the surface by forming spherical structures. Those spheres were usually considered to be secondary char, the reaction products of polycondensation of molecules derived from hydrolysis, mainly via HMF. At $160^{\circ} \mathrm{C}$, the formation of hydrochar occurred only to a limited degree during the regarded reaction time. Especially for longer reaction times, spherical structures appeared on the surface of the SPB. Contrary to this, at $200{ }^{\circ} \mathrm{C}$, the hydrochar 
was already formed as the reaction temperature was reached, which was represented by the sphere covered surface at $0 \mathrm{~h}$ (Figure $2 \mathrm{E}$ ) and was completely covered by microspheres. With the passage of time, the number of microspheres increased, eventually forming macrospheres via coagulation (Figure 2G) [44]. An immediate formation of char during the heating phase of the reactor was negligible for $160{ }^{\circ} \mathrm{C}$ with respect to the aforementioned production of char to a limited degree. Char formation started between $160{ }^{\circ} \mathrm{C}$ and $200{ }^{\circ} \mathrm{C}$ due to the degradation of the biopolymers and solid-to-solid conversion. An increase in reaction time also increased the density of the spheres across the surface, finally leading to a thicker layer of secondary char.
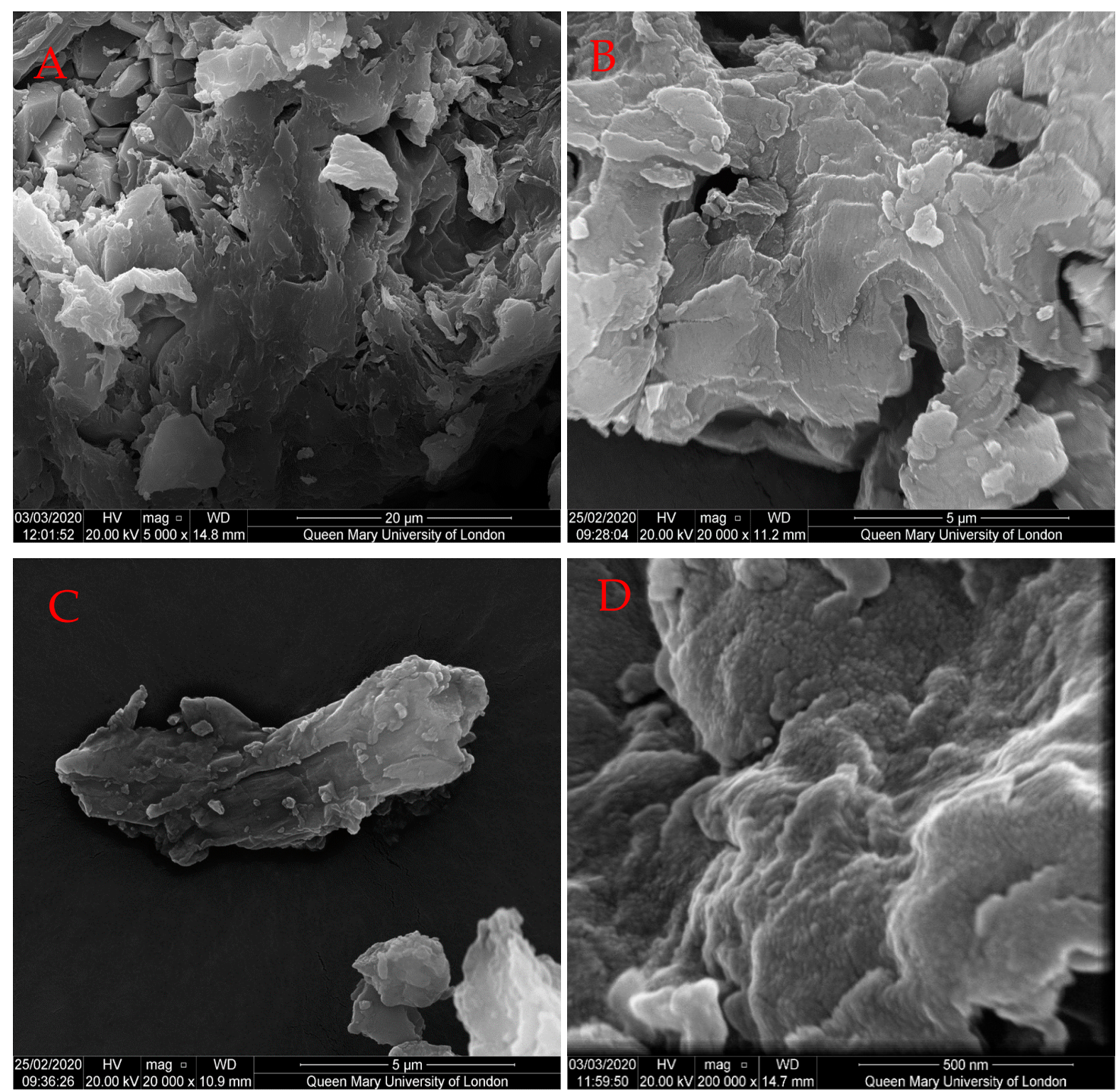

Figure 2. Cont. 

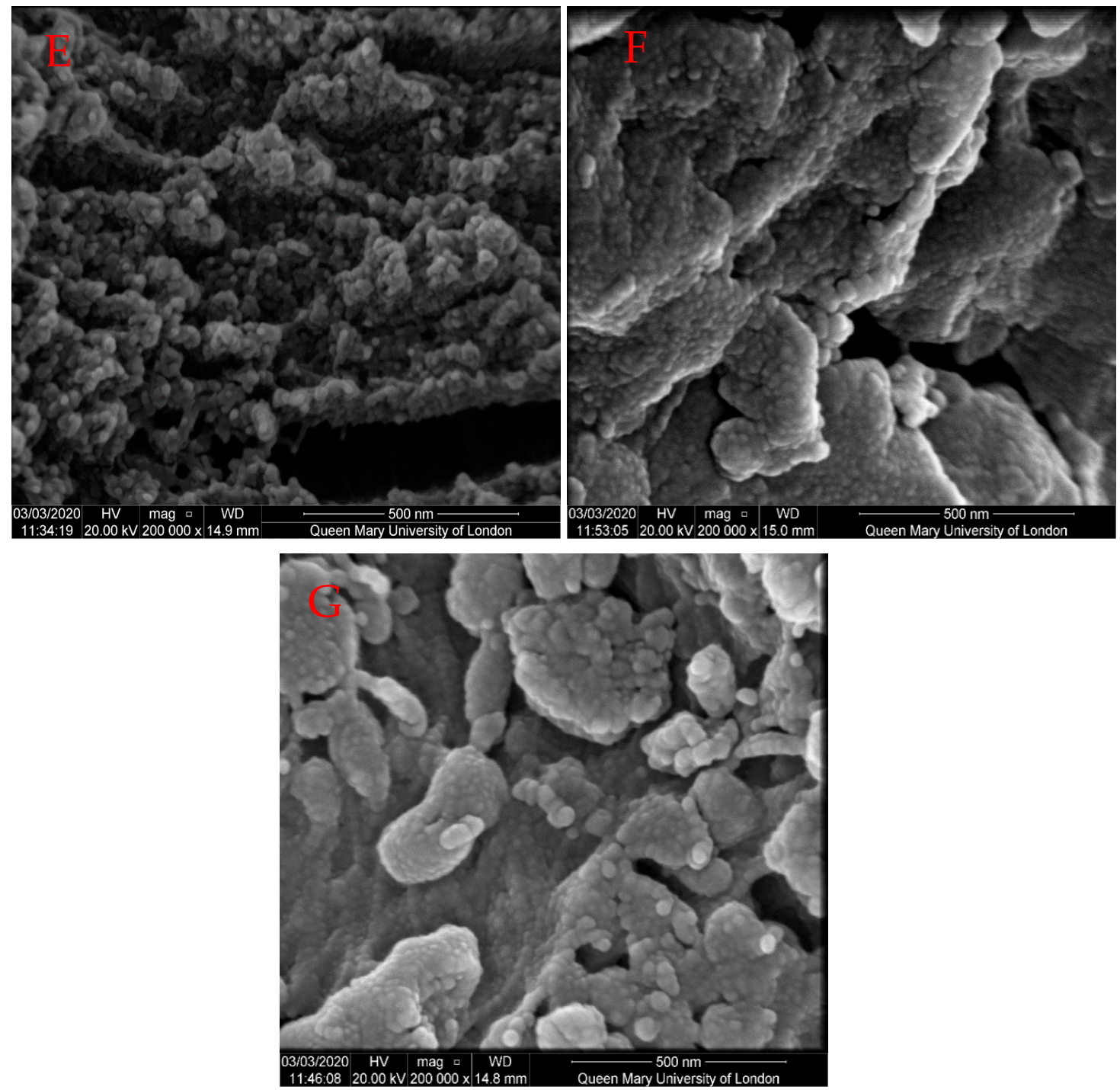

Figure 2. SEM images of raw SPB and chars after different reaction times at different temperatures.

(A) Raw, (B) S_160_0, (C) S_160_0.5, (D) S_160_1, (E) S_200_0, (F) S_200_0.5, (G) S_200_1.

What was not visible, even with the SEM, was the inner structure of the char particles. It can be assumed that the forming hydrochar layer covered unreacted biomass, as well as reactions that occurred inside. However, considering the SEM images, the formation of pyrochar was not clearly distinguishable from hydrochar formation due to the high amount of hydrochar covering. It was assumed that the "seeds" were formed by the pyrolysis pathway (Figure 1) around which the hydrothermal carbonization chars were grown [38]. At $200^{\circ} \mathrm{C}$, the temperature was high enough to start pyrochar formation to a comparatively high degree by converting more of the original biomass (decarboxylation and decarbonylation of undissolved biomass), thus leading to the formation of agglomerates and subsequently their precipitation [39]. This was one possible reason for the increased amount of chars in the SEM, especially considering the formation of hydrochar around pyrochar [38].

Figure 3 and Table $\mathrm{S} 3$ show the $\mathrm{O} / \mathrm{C}$ and $\mathrm{H} / \mathrm{C}$ atomic ratios of the produced hydrochars. As expected, the highest $\mathrm{O} / \mathrm{C}$ and $\mathrm{H} / \mathrm{C}$ atomic ratios were obtained for raw SPB (upper right corner of Figure 3). Compared with original SPB, the $\mathrm{O} / \mathrm{C}$ and $\mathrm{H} / \mathrm{C}$ atomic ratios of the hydrochars decreased. This decrease in $\mathrm{O} / \mathrm{C}$ and $\mathrm{H} / \mathrm{C}$ ratios was mainly due to dehydration and decarboxylation reactions that occurred during the HT process. Higher reaction temperatures and longer reaction times lead to hydrochars with properties similar to sub-bituminous coal, which can be used as a co-fuel $[9,45]$. By considering 
the results in literature [46-48], the obtained H/C and O/C ratios in Figure 3 were close to that of other solid fuels like coal, lignite and peat, thus showing their possibility to be used as co-fuels.

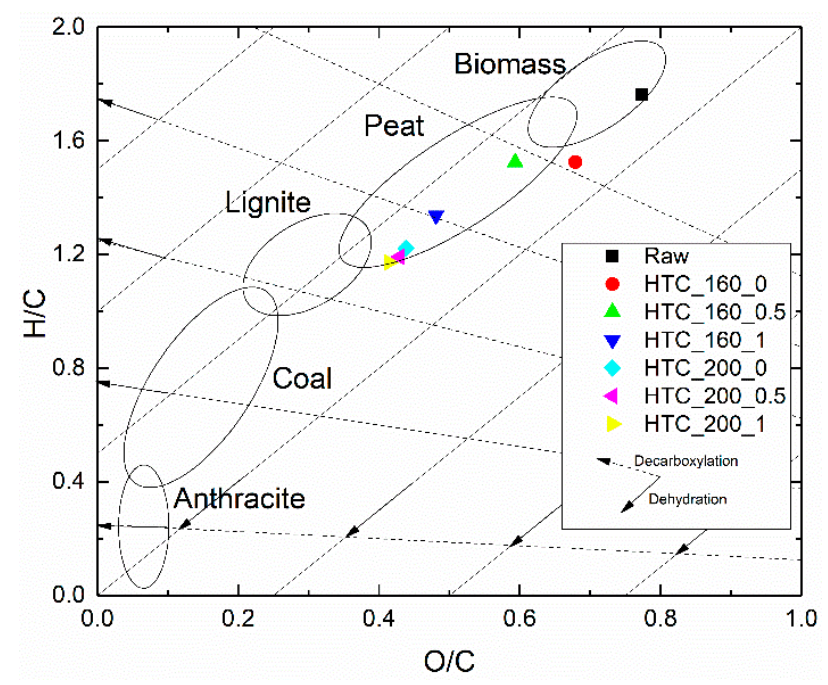

Figure 3. van Krevelen diagram of raw SPB and produced chars.

The higher heating value (HHV) of the hydrochars, produced at high temperatures, was around $22 \mathrm{MJ} / \mathrm{kg}$ (Table 3), which was similar to the HHV of HMF (22.06 MJ/kg) [49]. This was in good agreement with the hypothesis that intermediates (e.g., HMF) condensate to form hydrochars [50].

Table 3. Higher heating value (HHV), energy density $\left(E_{d}\right)$ and total yield $\left(Y_{\text {hydrochar }}\right)$ of the hydrochars and raw material.

\begin{tabular}{cccc}
\hline Sample & HHV [MJ/kg] $\mathbf{~}^{\mathbf{1}}$ & $\boldsymbol{E}_{\boldsymbol{d}}$ & $\boldsymbol{Y}_{\text {hydrochar }}$ [wt.\%] \\
\hline raw & 17.6 & & \\
S_160_0 & 18.4 & 1.0 & 63.2 \\
S_160_0.5 & 19.9 & 1.1 & 55.7 \\
S_160_1 & 21.6 & 1.2 & 53.1 \\
S_200_0 & 22.1 & 1.3 & 50.3 \\
S_200_0.5 & 22.4 & 1.3 & 51.6 \\
S_200_1 & 22.7 & 1.3 & 52.8 \\
\hline
\end{tabular}

${ }^{1} \mathrm{HHV}$ calculation by Channiwala and Parikh [51].

\subsection{Liquid Characterization}

Results of the HPLC analysis are given in Supplementary Information (Tables S1 and S2). The initial $\mathrm{pH}$ of SPB was 5.98; however, the $\mathrm{pH}$ after hydrolysis of SPB at $160{ }^{\circ} \mathrm{C}$ decreased with longer reaction times. This was proof that the hydrolysis pathways were proceeding as explained due to the starting degradation of hemicellulose and consequently beginning the formation of acids (acetic, lactic, levulinic, formic and propionic acids) [52]. At $200{ }^{\circ} \mathrm{C}$, the $\mathrm{pH}$ increased with the reaction time, implying the end of the conversion process and probable adsorbtion of formed acids on the chars. The lower concentration of dissolved organic carbon (DOC) at $200{ }^{\circ} \mathrm{C}$ confirmed the polymerization of intermediates to secondary char.

Cellulose is a linear polymer with high molecular weight and is composed of D-glucose units linked by $\beta-(1-4)$ glycosidic bonds [53,54]. In contrast, hemicellulose consists of different sugar monomers and exhibits branched chains. Both biopolymers undergo hydrolysis, but hemicellulose is more reactive because of its amorphous character. Hydrolysis reactions lead to the cleavage of ether bonds of cellulose by the attack of water. For each water molecule consumed, one molecule of glucose is produced. Water, which is an example of a polar protic solvent, also catalyzes the 
hydrolysis step by offering protons and hydroxyl ions [55]. The catalytic effect of water is more pronounced at higher temperatures and pressure due to its higher ionic product compared with ambient conditions $[7,56]$. This fact can be emphasized by the studies, which used Brønsted acids $(\mathrm{HCl}, \mathrm{HBr}$ and $\mathrm{H}_{2} \mathrm{SO}_{4}$ ) as catalysts [7]. As Brønsted acids offer protons that facilitate the breakdown of C-O-C glycosidic bonds between glucose units, they lead to a faster depolymerization of cellulose [57].

The composition of the liquid samples, obtained at different operating conditions, are shown in Figures 4 and 5 and Supplementary Information. At $160^{\circ} \mathrm{C}$ and $0 \mathrm{~h}$ reaction, the highest amount of glucose and fructose was obtained, and it was 40 times more than the concentration of HMF and levulinic acid. This meant that the primary products of hydrolysis of carbohydrates were in solution. As proposed by Körner et al., a higher $\mathrm{pH}$ leads to a lower production of HMF [6]. With a neutral or weak acidic $\mathrm{pH}$ at the beginning of the reaction and due to the low degradation of sugars, the $\mathrm{pH}$ of the process liquid at these conditions was consequently the highest of the displayed reactions. Thus, the high amount of sugars was only converted to a low degree to HMF. The increase in the reaction time led to a reduction of the glucose and fructose content in the liquid and an increase in their consecutive products (HMF, formic acid and levulinic acid). Nonetheless, the concentration of HMF was low compared to the projected possibilities mentioned by Körner et al. [6].

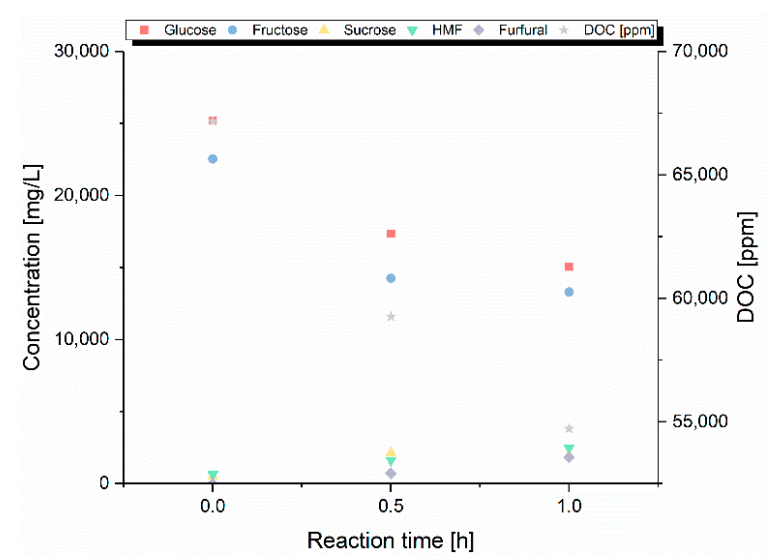

(A)

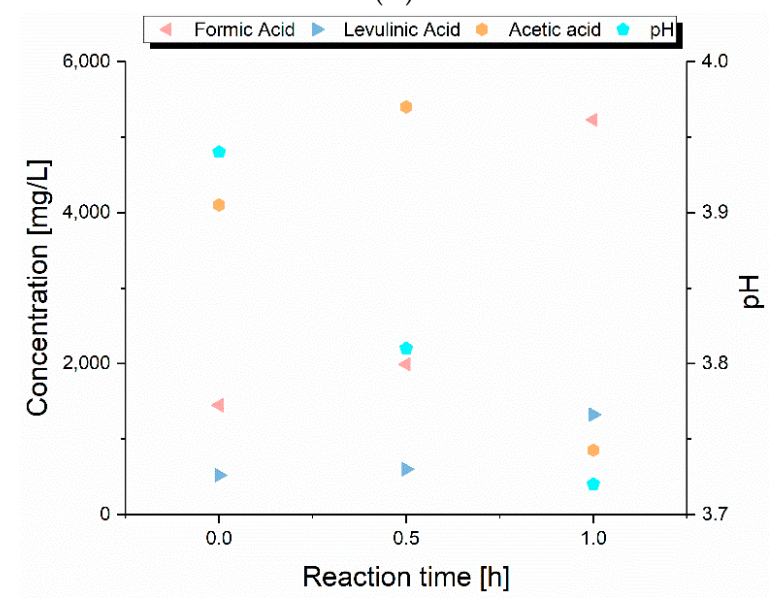

(B)

Figure 4. (A) Concentration of the sugars, 5-hydroxymethylfurfural (HMF) and furfural as well as dissolved organic carbon (DOC); (B) concentration of the acids in the process liquid and their $\mathrm{pH}$ after hydrothermal treatment $(\mathrm{HT})$ at $160^{\circ} \mathrm{C}$ for different reaction times. 


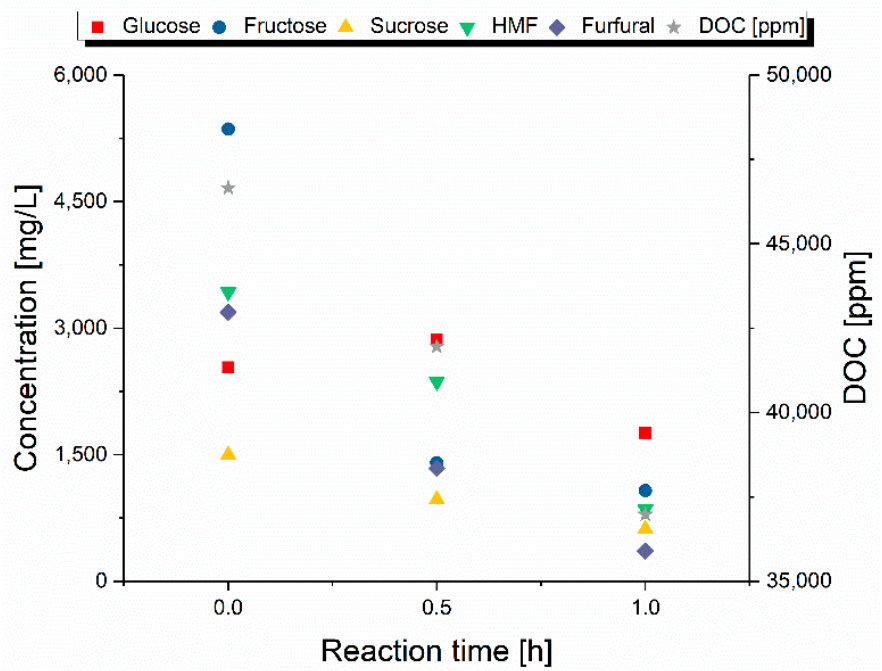

(A)

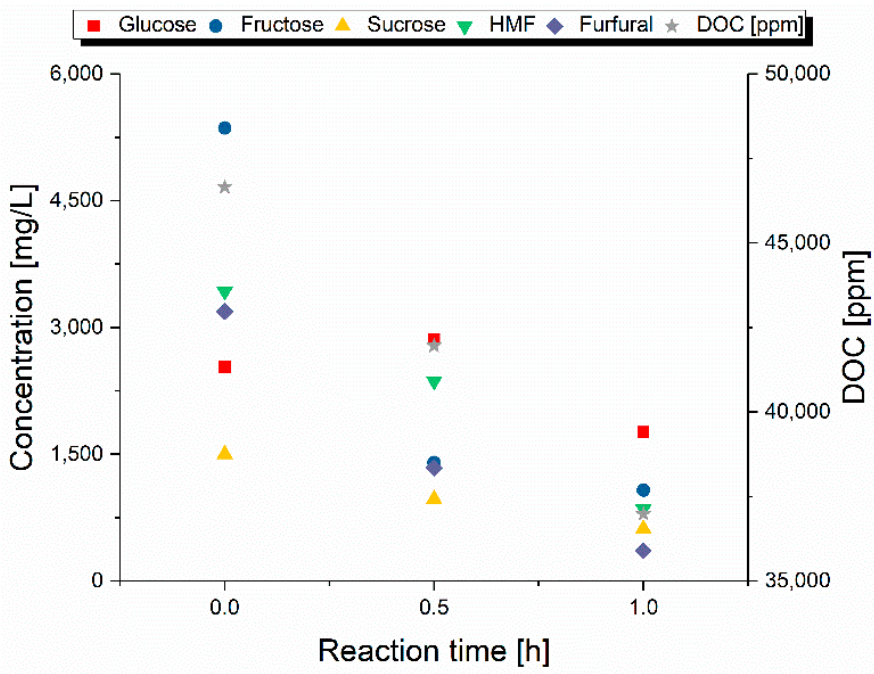

(B)

Figure 5. (A) Concentration of the sugars, HMF and furfural as well as dissolved organic carbon (DOC); (B) concentration of the acids in the process liquid and their $\mathrm{pH}$ after $\mathrm{HT}$ at $200{ }^{\circ} \mathrm{C}$ for different reaction times.

The lower amount of fructose compared with glucose found at $160{ }^{\circ} \mathrm{C}$ (Figure 4) implied that glucose was converted to HMF via isomerization to fructose by a reversible keto-enol tautomerism, as found by Lobry de Bruyn and Alberda van Ekenstein [58]. On the other hand, Li et al. [59] proposed that the catalytic conversion of glucose to fructose occurs via an enediol intermediate, which then forms fructose and finally builds HMF (Pathway I in Figure 6) or can directly dehydrate to HMF (Pathway II).

This is a critical step for the conversion of polymeric carbohydrates as well as biomass because glucose released from cellulose hydrolysis has a stable pyranose structure, which hampers the dehydration reaction [60].

Aldohexoses like glucose are less reactive; hence, ketohexoses like fructose are superior in producing HMF [6]. This higher reactivity increases the dehydration rate of ketohexoses, which thus react faster than aldohexoses, reducing the formation of unwanted byproducts such as organic acids or a tarry phase (called humins) [61]. As illustrated in Figure 6, fructose can be transformed into HMF with a loss of three water molecules (dehydration step 5) during an acid-catalyzed reaction. 


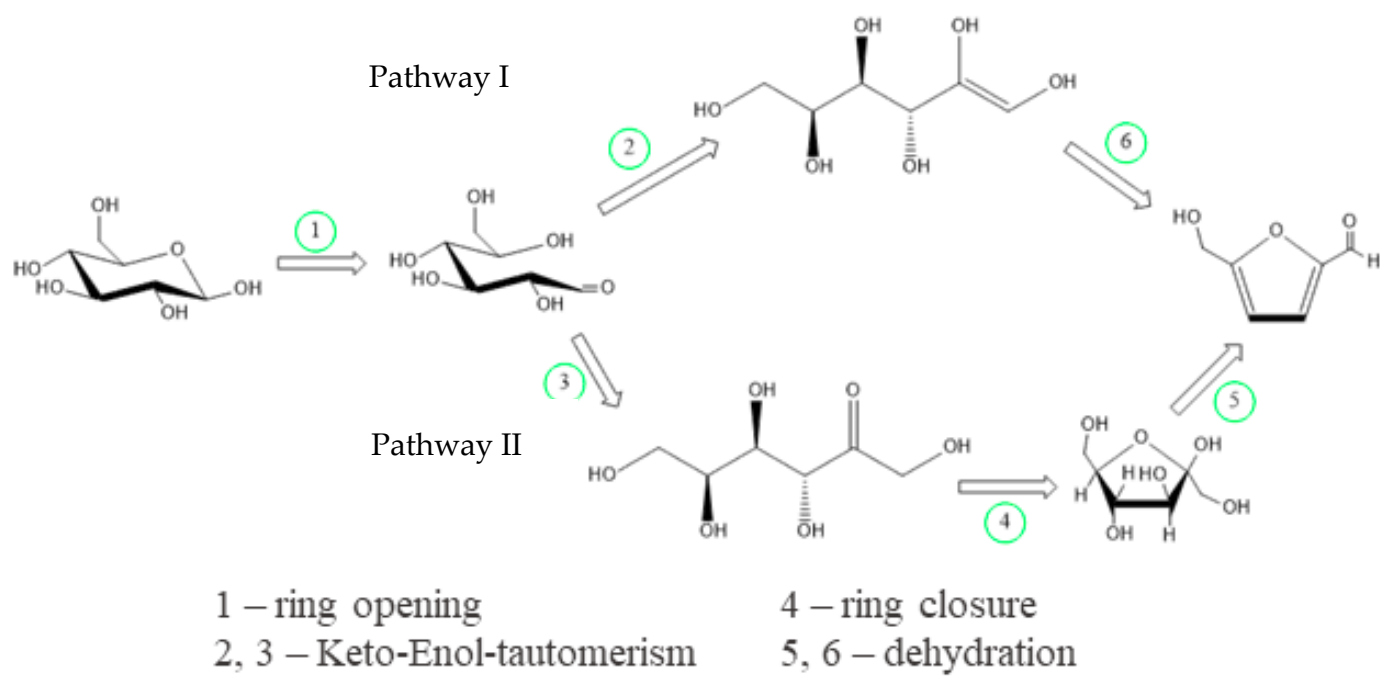

Figure 6. Isomerization of glucose to fructose and subsequent dehydration to form HMF; modified from Ji et al. [62].

Organic acids like acetic, formic and lactic acids are considered as possible catalysts for the conversion of fructose to HMF [62]. As can be seen from Figures 4 and 5, at higher acid concentrations, the highest amount of HMF was obtained, while it was shown by a study of Körner et al. that the maximum HMF yield was obtained at a $\mathrm{pH}$ around 3, even though a lower $\mathrm{pH}$ did not necessarily result in a higher HMF yield [7]. Therefore, the conditions of the present study should have had a high selectivity for HMF production, improved by the higher temperature applied. However, the studies mentioned worked with model compounds or solutions, while a real biomass like SPB consists of several other molecules which might affect its conversion behavior. As a result of the conversion of glucose and fructose, higher concentrations of HMF resulted in lower concentrations of both sugars, while the degradation of $\mathrm{HMF}$ could be seen at $200{ }^{\circ} \mathrm{C}$ for longer reaction times. These results showed that weak carboxylic acids at relatively high concentrations have the required acidity to convert fructose to HMF. This seems promising for developing the process at industrial scale. However, the process worked for fructose, but not for glucose because the concentration of glucose in the solution was still higher than fructose. This meant that the weak Brønsted acidity did not promote glucose isomerization to a high degree. In contrast, a strong Brønsted acidity could enhance the dehydration of glucose to HMF, bypassing the isomerization step [63]. Nevertheless, if the acidity is too high, unwanted reactions can occur such as polymerization between sugars and derivatives and rehydration of HMF to produce levulinic and formic acids [64].

At $200{ }^{\circ} \mathrm{C}$ and $0 \mathrm{~h}$ reaction time, the highest amount of HMF was obtained; however, the increase of the reaction time to $30 \mathrm{~min}$ led to a decrease in the HMF content and an increase in levulinic acid concentration. This effect can be explained by the fact that, under acidic conditions, HMF can be rehydrated to form levulinic and formic acids in aqueous media [65]. Furthermore, self-condensation of HMF and condensation with other compounds leads to the formation of polymeric substances called humins. These humins are built from HMF, and thus consist of furans and hydroxymethyl groups together with aromatic rings [66]. 2,5-Dioxo-6-hydroxyhexanal is supposed to be the key molecule for humin growth formed by rehydration of HMF [67]. However, in this study, no humins were observed after quenching of the HT reaction. This effect was opposite to that observed in previous studies, which reported the activation energies of the formation of humins originating from glucose $(51 \mathrm{~kJ} / \mathrm{mol})$ and $\operatorname{HMF}(142 \mathrm{~kJ} / \mathrm{mol})$ to be low enough that humins should have been formed $[68,69]$. Instead of humins, the formation of secondary char preferably occurred. 


\section{Materials and Methods}

\subsection{Material}

Spent sugar beets (SPB) with a water content of 50 wt.\% were provided by Südzucker AG. In order to avoid the microbial activity and ensure an equal biomass/water ratio for all the experiments, the biomass was dried at $105^{\circ} \mathrm{C}$ for $48 \mathrm{~h}$.

\subsection{Hydrothermal Treatment}

The experimental setup was described in another study of our research group [70]. HT tests were performed in a $250 \mathrm{~cm}^{3}$ stainless steel batch autoclave at temperatures of $160{ }^{\circ} \mathrm{C}$ and $200{ }^{\circ} \mathrm{C}$ and residence times of 0,30 and $60 \mathrm{~min}$. A reaction time of 0 min meant, after heating up to the desired temperature, the autoclave was directly removed from the oven. For each experiment, $40 \mathrm{~g}$ of the dry SPB was mixed with distilled water, keeping a fixed biomass/water ratio of 0.25 . After pre-heating, the reactors were held at the desired temperature. The temperature and pressure of the reactor were controlled throughout the whole reaction by a portable data logger (RSG 30 of Endress + Hauser). Once the reaction time was reached, the reactor was quenched in a cold-water bath for $30 \mathrm{~min}$. After the pressure was released, the solids and liquids were separated by vacuum filtration with a Büchner funnel and qualitative filter paper (pore size: $45 \mu \mathrm{m}$ ) from Whatman ${ }^{\circledR}$. The solid residue was dried at $105^{\circ} \mathrm{C}$ for at least $24 \mathrm{~h}$ and the $\mathrm{pH}$ of the separated liquids was recorded. Subsequently, the liquids were immediately stored under freezing conditions $\left(-24^{\circ} \mathrm{C}\right)$. All experiments were done in triplicate.

\subsection{Characterization of Biomass and Products}

\subsubsection{Solid Fraction}

A pre-dried sample $\left(105^{\circ} \mathrm{C}\right.$ for $\left.24 \mathrm{~h}\right)$ was used to determine the fiber composition of the SPB by Fibretherm FT12. The determination of acid detergent lignin (ADL), neutral detergent fiber (NDF) and acid detergent fiber (ADF) was conducted according to Van Soest's method [71,72]. Cellulose, hemicellulose and lignin, the main components of the fiber, were determined according to Reza et al. [50].

The homogeneity of the samples was ensured by grounding them with a CryoMill from Retsch $\mathrm{GmbH}$ for two minutes at $1800 \mathrm{rpm}$, before the determination of the elemental composition of the SPB and hydrochars. Carbon $(\mathrm{C})$, hydrogen $(\mathrm{H})$, nitrogen $(\mathrm{N})$ and sulfur $(\mathrm{S})$ contents were determined by an elemental analyzer (EuroEA3000 Serie CHNS-O of EuroVector S.p.A) equipped with a thermal conductivity detector (TCD). The oxygen $(\mathrm{O})$ content was calculated by subtraction of the previously determined elemental contents (C, H, N and S) as well as the ash content from 100\% [73]. Volatile matter (VM), fixed carbon (FC) and ash content were worked out according to previous studies by Cao et al. [73].

To display the influence of HT on the structures of the surface and to pursue the carbonization of the solid sample, the scanning electron microscope (SEM) FEI Inspect-F, from Queen Mary University in London, was used. A small amount of dry sample was fixed on a carbon tab on the sample holder and sputtered with gold for $90 \mathrm{~s}$. After applying high vacuum, images of the samples were taken.

Solid samples were named as S_XX_YY, where XX denoted the reaction temperature and YY denoted the reaction time (e.g., S_200_0 was the solid product of HT at $200{ }^{\circ} \mathrm{C}$ and 0 min, just after heating).

\subsubsection{Liquid Fraction}

The dissolved organic carbon (DOC) of the liquid samples, previously filtered with a $45 \mu \mathrm{m}$ Polytetrafluorethylen (PTFE) syringe filter, was determined using the TOC Analyzer 5050A (Shimadzu Scientific Instruments, Columbia, MD, USA). In the next step, the liquids were again filtered with a $13 \mu \mathrm{m}$ PTFE syringe filter, before the determination of the liquid phase by High-Performance Liquid Chromatography (HPLC) with Shimadzu 20AD. Furthermore, the samples were diluted to 1:10 with 
distilled water to fit the concentrations of the standard calibration. With an Aminex HPX-87H column, the liquid samples were analyzed for their contents. The eluent used was $4 \mathrm{mM} \mathrm{H}_{2} \mathrm{SO}_{4}$ at a flow rate of $0.65 \mathrm{~mL} / \mathrm{min}$ and an oven temperature of $25^{\circ} \mathrm{C}$. A more detailed description as well as a discussion of the HPLC method are given in Wüst et al. [74]. All results were directly adjusted with their dilution factor.

Liquid samples were named analogously to the solid samples as L_XX_YY (e.g., L_200_0).

\subsection{Error Estimation}

All samples were prepared with the same procedure; nonetheless, some device-specific errors could have occurred. Balances in the laboratory work were made with an internal uncertainty of $0.005 \mathrm{~g}$ for the preparation of the experiment and $0.005 \mathrm{mg}$ for the analysis of the samples. Results of the elemental analysis (EA) were mean values of triplicate measurements of each sample, ensuring that the differences were below $0.5 \%$ in-between the measurements. The determination of the composition of the raw spent sugar beets was also performed in triplicate and the uncertainty was $0.05 \mathrm{wt} . \%$. As mentioned in the Supplementary Information in Tables S1 and S2, the uncertainty of the HPLC was below $0.05 \mathrm{~g} / \mathrm{L}$ due to dilution and internal uncertainty of the device.

\section{Conclusions}

At two temperatures, the selectivity of the formation of products from hydrolysis and further on from hydrothermal conversion was evaluated. At $160^{\circ} \mathrm{C}$ and $0 \mathrm{~h}$, the hydrolysis of biopolymers like cellulose had already started, expressed by the highest sugar contents in the liquid with $25 \mathrm{~g} / \mathrm{L}$ of glucose and $22 \mathrm{~g} / \mathrm{L}$ of fructose, while the conversion to degradation products of the sugars was comparatively low. This revealed a higher yield of sugars compared with other biomasses like miscanthus or other lignocellulosic biomass at any time at $160{ }^{\circ} \mathrm{C}$ in a batch or at $180{ }^{\circ} \mathrm{C}$ in a semi-batch process, each with a catalyst $[75,76]$. With longer reaction times, the concentration of the sugars decreased until $15 \mathrm{~g} / \mathrm{L}$ of glucose and $13 \mathrm{~g} / \mathrm{L}$ of fructose were found. At $200{ }^{\circ} \mathrm{C}$, the trend was opposite for conversion products like acids and $\mathrm{HMF}$, whose yield decreased with longer reaction times. The highest concentration of $\mathrm{HMF}$ was obtained at $200{ }^{\circ} \mathrm{C}$ and $0 \mathrm{~h}$ with $3.4 \mathrm{~g} / \mathrm{L}$, which was comparable to the yield of the semi-batch process with a catalyst of lignocellulosic biomasses at the same temperature [75]. Compared with the theoretically possible concentrations using a model compound like fructose, the concentration in the present study did not reach the maximum yet [6]. An optimization of the process parameters (reaction temperature and time) is still necessary to increase the yield of HMF, which should be high with the amount of sugar still present in the spent sugar beets. An optimization of the process parameters is possible by considering the approach of the kinetic modeling of the reactions and optimization of the process parameters reported by Jung et al. $[6,7,77]$. This will be the subject of future research.

An inclusion of spent sugar beets in biorefineries is possible by considering their use as biofuels. While the raw biomass exhibited an $\mathrm{H} / \mathrm{C}$ ratio of 1.8 , it decreased throughout the reactions, resulting in a ratio of 1.2 for the hydrochar after carbonization for $1 \mathrm{~h}$ at $200{ }^{\circ} \mathrm{C}$. This was supported by the increase in the higher heating value up to $22.7 \mathrm{MJ} / \mathrm{kg}$, which was closer to that of subbituminous coal $(24.3 \mathrm{MJ} / \mathrm{kg})$ and higher than that of lignite $(20.9 \mathrm{MJ} / \mathrm{kg})[45]$.

Supplementary Materials: The following are available online. Table S1: Concentration of the sugars in the process liquid, $\mathrm{pH}$ and dissolved organic carbon (DOC) after HT; the error was estimated to be $0.05[\mathrm{~g} / \mathrm{L}]$ due to dilution errors and high concentrations, Table S2: Concentration of the acids, HMF and furfural in the process liquid after $\mathrm{HT}$; the error was estimated to be $0.05[\mathrm{~g} / \mathrm{L}]$ due to dilution errors and high concentrations, Table S3: $\mathrm{O} / \mathrm{C}$ and $\mathrm{H} / \mathrm{C}$ ratios of the hydrochars and raw material.

Author Contributions: Conceptualization, J.P., P.J.A., P.M. and M.L.; methodology, J.P., P.J.A., P.M. and M.L.; validation, J.P., P.J.A., P.M. and M.L.; formal analysis, J.P., P.J.A. and P.M.; investigation, J.P., P.M. and M.L. resources, J.P., P.M. and M.L.; writing—original draft preparation, J.P., P.J.A., P.M. and M.L.; writing-review and editing, J.P., M.-M.T., L.F. and A.K.; supervision, M.-M.T., L.F. and A.K.; project administration, M.-M.T. and A.K.; funding acquisition, M.-M.T. and A.K. All authors have read and agreed to the published version of the manuscript. 
Funding: The present work was funded by the Deutsche Forschungsgemeinschaft (DFG, German Research Foundation)-328017493/GRK 2366 (Sino-German International Research Training Group AMAIZE-P) and the European Union's Horizon 2020 research and innovation program under the Marie Skłodowska-Curie Grant Agreement No. 721991.

Acknowledgments: The authors also like to thank Tom Wischnewski and Katarzyna Swiatek for their technical assistant support with experiments and analysis.

Conflicts of Interest: The authors declare no conflict of interest. The funders had no role in the design of the study; in the collection, analyses, or interpretation of data; in the writing of the manuscript, or in the decision to publish the results.

\section{References}

1. Ryan, L.; Convery, F.; Ferreira, S. Stimulating the use of biofuels in the European Union: Implications for climate change policy. Energy Policy 2006, 34, 3184-3194. [CrossRef]

2. Huber, G.W.; Iborra, S.; Corma, A. Synthesis of transportation fuels from biomass: Chemistry, catalysts, and engineering. Chem. Rev. 2006, 106, 4044-4098. [CrossRef] [PubMed]

3. Schwald, W.; Bobleter, O. Hydrothermolysis of cellulose under static and dynamic conditions at high temperatures. J. Carbohydr. Chem. 1989, 8, 565-578. [CrossRef]

4. Titirici, M.-M. Sustainable Caron Materials from Hydrothermal Processes; John Wiley \& Sons Ltd.: Hoboken, NJ, USA, 2013.

5. Paksung, N.; Pfersich, J.; Arauzo, P.J.; Jung, D.; Kruse, A. Structural effects of cellulose on hydrolysis and carbonization behavior during hydrothermal treatment. ACS Omega 2020, 5, 12210-12223. [CrossRef]

6. Körner, P.; Jung, D.; Kruse, A. Influence of the $\mathrm{pH}$ value on the hydrothermal degradation of fructose. ChemistryOpen 2019, 8, 1121-1132. [CrossRef] [PubMed]

7. Körner, P.; Jung, D.; Kruse, A. The effect of different Brønsted acids on the hydrothermal conversion of fructose to HMF. Green Chem. 2018, 20, 2231-2241. [CrossRef]

8. Reza, M.T.; Rottler, E.; Herklotz, L.; Wirth, B. Hydrothermal carbonization (HTC) of wheat straw: Influence of feedwater $\mathrm{pH}$ prepared by acetic acid and potassium hydroxide. Bioresour. Technol. 2015, 182, 336-344. [CrossRef]

9. Ulbrich, M.; Preßl, D.; Fendt, S.; Gaderer, M.; Spliethoff, H. Impact of HTC reaction conditions on the hydrochar properties and CO2 gasification properties of spent grains. Fuel Process. Technol. 2017, 167, 663-669. [CrossRef]

10. Xia, H.; Xu, S.; Hu, H.; An, J.; Li, C. Efficient conversion of 5-hydroxymethylfurfural to high-value chemicals by chemo- and bio-catalysis. RSC Adv. 2018, 8, 30875-30886. [CrossRef]

11. Saravanamurugan, S.; Pandey, A.; Hu, L.; Riisager, A. Biomass, Biofuels, Biochemicals: Recent Advances in Devvelopment of Platform Chemicals; Elsevier B.V.: Amsterdam, The Netherlands, 2020.

12. Li, Y.M.; Zhang, X.Y.; Li, N.; Xu, P.; Luo, W.-Y.; Zong, M.-H. Biocatalytic Reduction of HMF to 2,5-Bis(hydroxymethyl)furan by HMF-Tolerant Whole Cells. ChemSusChem 2017, 10, 372-378. [CrossRef]

13. Davis, S.E.; Zope, B.N.; Davis, R.J. On the mechanism of selective oxidation of 5-hydroxymethylfurfural to 2,5-furandicarboxylic acid over supported Pt and Au catalysts. Green Chem. 2012, 14, 143-147. [CrossRef]

14. Li, F.; Li, X.L.; Li, C.; Shi, J.; Fu, Y. Aerobic oxidative esterification of 5-hydroxymethylfurfural to dimethyl furan-2,5-dicarboxylate by using homogeneous and heterogeneous $\mathrm{PdCoBi} / \mathrm{C}$ catalysts under atmospheric oxygen. Green Chem. 2018, 20, 3050-3058. [CrossRef]

15. Nguyen, H.; Nikolakis, V.; Vlachos, D.G. Mechanistic insights into lewis acid metal salt-catalyzed glucose chemistry in aqueous solution. ACS Catal. 2016, 6, 1497-1504. [CrossRef]

16. Tong, Z.; Pullammanappallil, P.; Teixeira, A.A. How Ethanol Is Made from Cellulosic Biomass. Available online: https://edis.ifas.ufl.edu (accessed on 3 April 2020).

17. Kessler, M.T.; Scholten, J.D.; Prechtl, M.H.G. Metal Catalysts immobilised in Ionic Liquids: A Couple with Opportunities for Fine Chemicals Derived from Biomass. In New and Future Development in Catalysis: Hybrid Materials, Composites, and Organocatalysts; Suib, S.L., Ed.; Elsevier: Amsterdam, The Netherlands, 2013. [CrossRef]

18. Xue, Z.; Ma, M.G.; Li, Z.; Mu, T. Advances in the conversion of glucose and cellulose to 5-hydroxymethylfurfural over heterogeneous catalysts. RSC Adv. 2016, 6, 98874-98892. [CrossRef] 
19. Kruse, A.; Zevaco, T.A. Properties of hydrochar as function of feedstock, reaction conditions and post-treatment. Energies 2018, 11, 674. [CrossRef]

20. Karayildirim, T.; Sinağ, A.; Kruse, A. Char and coke formation as unwanted side reaction of the hydrothermal biomass gasification. Chem. Eng. Technol. 2008, 31, 1561-1568. [CrossRef]

21. Fasahat, P.; Aghaeezadeh, M.; Jabbari, L.; Sadeghzadeh Hemayati, S.; Townson, P. Sucrose accumulation in sugar beet: From fodder beet selection to genomic selection. Sugar Tech. 2018, 20, 635-644. [CrossRef]

22. Risser, D.; Baltruschat, N. Suedzucker Reports Strong 3rd Quarter in Fiscal 2019/2020. Available online: https://www.suedzucker.de/en/press/sudzucker-reports-strong-3rd-quarter-fiscal-201920 (accessed on 27 April 2020).

23. Donovan, M. Refining of Sugarbeet and Sugarcane; Academic Press: New York, NY, USA, 1993.

24. Ziemiński, K.; Romanowska, I.; Kowalska-Wentel, M.; Cyran, M. Effects of hydrothermal pretreatment of sugar beet pulp for methane production. Bioresour. Technol. 2014, 166, 187-193. [CrossRef]

25. Rempe, C.; Maschkowski, G.; Lobitz, R. Zucker. 2020. Available online: https://www.bzfe.de/inhalt/zucker31842.html (accessed on 2 April 2020).

26. Negahdar, L.; Delidovich, I.; Palkovits, R. Aqueous-phase hydrolysis of cellulose and hemicelluloses over molecular acidic catalysts: Insights into the kinetics and reaction mechanism. Appl. Catal. B Environ. 2016, 184, 285-298. [CrossRef]

27. Schnepf, E. Structure of cell walls and cellulose fibrils in glaucocystis. Planta 1965, 67, 213-224. [CrossRef]

28. Tieke, B.; Lechner, M.D.; Gehrke, K.; Nordmeier, E.H. Makromolekulare Chemie. Chemistry and Physics; Springer: Berlin/Heidelberg, Germany, 2014. [CrossRef]

29. Sjöström, E. Wood Chemistry: Fundamentals and Applications; Academic Press: New York, NY, USA, 1993.

30. Deguchi, S.; Tsujii, K.; Horikoshi, K. Crystalline-to-amorphous transformation of cellulose in hot and compressed water and its implications for hydrothermal conversion. Green Chem. 2008, 10, 191-196. [CrossRef]

31. Yu, Y.; Wu, H. Significant differences in the hydrolysis behavior of amorphous and crystalline portions within microcrystalline cellulose in hot-compressed water. Ind. Eng. Chem. Res. 2010, 49, 3902-3909. [CrossRef]

32. Falco, C.; Baccile, N.; Titirici, M.M. Morphological and structural differences between glucose, cellulose and lignocellulosic biomass derived hydrothermal carbons. Green Chem. 2011, 13, 3273-3281. [CrossRef]

33. Dinjus, E.; Kruse, A.; Tröger, N. Hydrothermale karbonisierung: 1. einfluss des lignins in lignocellulosen. Chem. Ing. Tech. 2011, 83, 1734-1741. [CrossRef]

34. Sitko, R.; Zawisza, B. Quantification in X-ray Fluorescence Spectrometry. In X-ray Spectroscopy; Sharma, S.K., Ed.; InTech: Rijeka, Croatia, 2012.

35. Ok, Y.S.; Tsang, D.C.W.; Bolan, N.; Novak, J.M. Biochar from Biomass and Waste: Fundamentals and Applications; Elsevier: Amsterdam, The Netherlands, 2018. [CrossRef]

36. Gagić, T.; Perva-Uzunalić, A.; Knez, Ž.; Škerget, M. Hydrothermal degradation of cellulose at temperature from 200 to $300{ }^{\circ} \mathrm{C}$. Ind. Eng. Chem. Res. 2018, 57, 6576-6584. [CrossRef]

37. Reza, M.T.; Becker, W.; Sachsenheimer, K.; Mumme, J. Hydrothermal carbonization (HTC): Near infrared spectroscopy and partial least-squares regression for determination of selective components in HTC solid and liquid products derived from maize silage. Bioresour. Technol. 2014, 161, 91-101. [CrossRef]

38. Lucian, M.; Volpe, M.; Gao, L.; Piro, G.; Goldforb, G.L.; Fiori, L. Impact of hydrothermal carbonization conditions on the formation of hydrochars and secondary chars from the organic fraction of municipal solid waste. Fuel 2018, 233, 257-268. [CrossRef]

39. Lucian, M.; Volpe, M.; Fiori, L. Hydrothermal carbonization kinetics of lignocellulosic agro-wastes: Experimental data and modeling. Energies 2019, 12, 516. [CrossRef]

40. Kruse, A.; Funke, A.; Titirici, M.-M. Hydrothermal conversion of biomass to fuels and energetic materials. Curr. Opin. Chem. Biol. 2013, 17, 515-521. [CrossRef]

41. Jatzwauck, M.; Schumpe, A. Kinetics of hydrothermal carbonization (HTC) of soft rush. Biomass Bioenergy 2015, 75, 94-100. [CrossRef]

42. Baratieri, M.; Basso, D.; Patuzzi, F.; Castello, D.; Fiori, L. Kinetic and thermal modeling of hydrothermal carbonization applied to grape marc. Chem. Eng. Trans. 2015, 43, 505-510.

43. Kannan, S.; Gariepy, Y.; Raghavan, G.S.V. Optimization and characterization of hydrochar produced from microwave hydrothermal carbonization of fish waste. Waste Manag. 2017, 65, 159-168. [CrossRef] [PubMed] 
44. Jung, D.; Zimmermann, M.; Kruse, A. Hydrothermal carbonization of fructose: Growth mechanism and kinetic model. ACS Sustain. Chem. Eng. 2018, 6, 13877-13887. [CrossRef]

45. Fan, F.; Yang, Z.; Li, H.; Shi, Z.; Kan, H. Preparation and properties of hydrochars from macadamia nut shell via hydrothermal carbonization. R. Soc. Open Sci. 2018, 5, 181126. [CrossRef]

46. Orem, W.H.; Finkelman, R.B. Coal Formation and Geochemistry. In Treatise on Geochemistry; Elsevier-Pergamon: Oxford, UK, 2003; pp. 191-222.

47. Carrasco, S.; Silva, J.; Pino-Cortés, E.; Gómez, J.; Vallejo, F.; Díaz-Robles, L.; Campos, V.; Cubillos, F.; Pelz, S.; Paczkowski, S.; et al. Experimental study on hydrothermal carbonization of lignocellulosic biomass with magnesium chloride for solid fuel production. Processes 2020, 8, 444. [CrossRef]

48. Arauzo, P.J.; Olszewski, M.P.; Wang, X.; Pfersich, J.; Sebastian, V.; Manyà, J.; Hedin, N.; Kruse, A. Assessment of the effects of process water recirculation on the surface chemistry and morphology of hydrochar. Renew. Energy 2020, 155, 1173-1180. [CrossRef]

49. Brebbia, C.A.; Sendra, J.J. Energy and Sustainability VII; WIT Press: Southampton, UK, 2017.

50. Reza, M.T.; Uddin, M.H.; Lynam, J.G.; Hoekman, S.K.; Coronella, C.J. Hydrothermal carbonization of loblolly pine: Reaction chemistry and water balance. Biomass Convers. Biorefinery 2014, 4, 311-321. [CrossRef]

51. Channiwala, S.A.; Parikh, P.P. A unified Correlation for Estimating HHV of Solid, Liquid and Gaseous Fuels. Available online: http://www.fuel (accessed on 21 May 2020).

52. Delbecq, F.; Wang, Y.; Muralidhara, A.; Ouardi, K.E.; Marlair, G.; Len, C. Hydrolysis of Hemicellulose and Derivatives-A Review of Recent Advances in the Production of Furfural. Front. Chem. 2018, 6, 146. [CrossRef]

53. Pelley, J.W. Elsevier's Integrated Review Biochemistry; Elsevier Inc.: Philadelphia, PA, USA, 2012.

54. Achyuthan, K.E.; Achyuthan, A.M.; Adams, P.D.; Dirk, S.M.; Harper, J.C.; Simmons, B.A.; Singh, A.K. Supramolecular self-assembled chaos: Polyphenolic lignin's barrier to cost-effective lignocellulosic biofuels. Molecules 2010, 15, 8641-8688. [CrossRef]

55. Möller, M.; Harnisch, F.; Schröder, U. Hydrothermal liquefaction of cellulose in subcritical water-the role of crystallinity on the cellulose reactivity. RSC Adv. 2013, 3, 11035-11044. [CrossRef]

56. Kruse, A.; Dinjus, E. Hot compressed water as reaction medium and reactant. Properties and synthesis reactions. J. Supercrit. Fluids 2007, 39, 362-380. [CrossRef]

57. Tao, F.; Song, H.; Chou, L. Catalytic conversion of cellulose to chemicals in ionic liquid. Carbohydr. Res. 2011, 346, 58-63. [CrossRef]

58. de Bruyn, C.A.L.; van Ekenstein, W.A. Action des alcalis sur les sucres, II. Transformation réciproque des uns dans les autres des sucres glucose, fructose et mannose. Recl. Trav. Chim. Pays-Bas 1895, 14, 203-216. [CrossRef]

59. Li, J.; Li, J.; Zhang, D.; Liu, C. Theoretical Elucidation of Glucose Dehydration to 5-Hydroxymethylfurfural Catalyzed by a SO3H-Functionalized Ionic Liquid. J. Phys. Chem. B 2015, 119, 13398-13406. [CrossRef] [PubMed]

60. Carraher, J.M.; Fleitman, C.N.; Tessonnier, J.P. Kinetic and mechanistic study of glucose isomerization using homogeneous organic brønsted base catalysts in water. ACS Catal. 2015, 5, 3162-3173. [CrossRef]

61. Siqueira, B.G.; Silva, M.A.P.; Moraes, C. Synthesis of hmf from glucose in aqueous medium using niobium and titanium oxides. Braz. J. Pet. Gas. 2013, 7,71-82. [CrossRef]

62. de Souza, R.L.; Yu, H.; Rataboul, F.; Essayem, N. 5-Hydroxymethylfurfural (5-HMF) production from hexoses: Limits of heterogeneous catalysis in hydrothermal conditions and potential of concentrated aqueous organic acids as reactive solvent system. Challenges 2012, 3, 212-232. [CrossRef]

63. Yang, L.; Tsilomelekis, G.; Caratzoulas, S.; Vlachos, D.G. Mechanism of brønsted acid-catalyzed glucose dehydration. ChemSusChem 2015, 8, 1334-1341. [CrossRef]

64. Hu, L.; Zhao, G.; Tang, X.; Wu, Z.; Xu, J.; Lin, L.; Liu, S. Catalytic conversion of carbohydrates into 5-hydroxymethylfurfural over cellulose-derived carbonaceous catalyst in ionic liquid. Bioresour. Technol. 2013, 148, 501-507. [CrossRef]

65. Tschirner, S.; Weingart, E.; Teevs, L.; Prüße, U. Catalytic dehydration of fructose to 5-hydroxymethylfurfural (hmf) in low-boiling solvent hexafluoroisopropanol (HFIP). Molecules 2018, 23, 1866. [CrossRef]

66. Steinbach, D.; Kruse, A.; Sauer, J. Pretreatment technologies of lignocellulosic biomass in water in view of furfural and 5-hydroxymethylfurfural production-A review. Biomass Convers. Biorefinery 2017, 7, 247-274. [CrossRef] 
67. Patil, S.K.R.; Lund, C.R.F. Formation and growth of humins via aldol addition and condensation during acid-catalyzed conversion of 5-hydroxymethylfurfural. Energy Fuels 2011, 25, 4745-4755. [CrossRef]

68. Weingarten, R.; Cho, J.; Xing, R.; Conner, W.C.; Huber, G.W. Kinetics and reaction engineering of levulinic acid production from aqueous glucose solutions. ChemSusChem 2012, 5, 1280-1290. [CrossRef] [PubMed]

69. Wang, T.; Nolte, M.W.; Shanks, B.H. Catalytic dehydration of C6 carbohydrates for the production of hydroxymethylfurfural (HMF) as a versatile platform chemical. Green Chem. 2014, 16, 548-572. [CrossRef]

70. Rodríguez Correa, C.; Stollovsky, M.; Hehr, T.; Rauscher, Y.; Rolli, B.; Kruse, A. Influence of the Carbonization Process on Activated Carbon Properties from Lignin and Lignin-Rich Biomasses. ACS Sustain. Chem. Eng. 2017, 5, 8222-8233. [CrossRef]

71. Goering, H.K.; Van Soest, P.J. Forage Fiber Analyses; USDA Agricultural Research Service: Washington, DC, USA, 1970; pp. 1-24.

72. Jung, H.-J.G. Analysis of forage fiber and cell walls in ruminant nutrition. J. Nutr. 1997, 127, 810S-813S. [CrossRef]

73. Cao, Z.; Jung, D.; Olszewski, M.P.; Arauzo, P.J.; Kruse, A. Hydrothermal carbonization of biogas digestate: Effect of digestate origin and process conditions. Waste Manag. 2019, 100, 138-150. [CrossRef]

74. Wüst, D.; Correa, C.R.; Jung, D.; Zimmermann, M.; Kruse, A.; Fiori, L. Understanding the influence of biomass particle size and reaction medium on the formation pathways of hydrochar. Biomass Convers. Biorefinery 2019, 1-4. [CrossRef]

75. Świątek, K.; Gaag, S.; Klier, A.; Kruse, A.; Sauer, J.; Steinbach, D. Acid hydrolysis of lignocellulosic biomass: Sugars and furfurals formation. Catalysts 2020, 10, 437. [CrossRef]

76. Yang, F.; Afzal, W.; Cheng, K.; Liu, N.; Pauly, M.; Bell, A.T.; Liu, Z.; Prausnitz, J.M. Nitric-acid hydrolysis of Miscanthus giganteus to sugars fermented to bioethanol. Biotechnol. Bioprocess. Eng. 2015, 20, 304-314. [CrossRef]

77. Jung, D.; Körner, P.; Kruse, A. Kinetic study on the impact of acidity and acid concentration on the formation of 5-hydroxymethylfurfural (HMF), humins, and levulinic acid in the hydrothermal conversion of fructose. Biomass Convers. Biorefinery 2019, 1-16. [CrossRef]

Sample Availability: Samples of the compounds are not available from the authors.

(C) 2020 by the authors. Licensee MDPI, Basel, Switzerland. This article is an open access article distributed under the terms and conditions of the Creative Commons Attribution (CC BY) license (http://creativecommons.org/licenses/by/4.0/). 